"El testamento cinematográfico del español Luis Buñuel a través de sus últimas películas francesas". Le dernier Buñuel de Arnaud Duprat, Rennes, Presses Universitaires de Rennes, Collection "Le Spectaculaire”, 2011, 307 pp.

\section{Le dernier Buñuel}

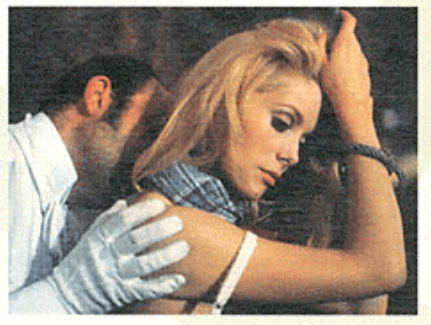

Arnaud Duprat

Préface de deanflaste Cinitric

En el libro Le dernier Buñuel de Arnaud Duprant -fruto de su tesis doctoral Les derniers films de Luis Buñuel: l'aboutissement d'une pensée Cinématographique- se plantea un análisis de su obra partiendo del final, por la consideración de que en las seis últimas películas -Belle de jour (1967), La Vía Láctea (La Voie Lactée, 1969), Tristana (1970), El discreto encanto de la burguesía (Le charme discret de la bourgeoisie, 1972), El fantasma de la libertad (Le fantôme de la liberté, 1974) y Ese oscuro objeto del deseo (Cet obscur objet du désir, 1977)-, las realizadas desde que volviera a Francia desde México, se encontrara el testamento cinematográfico del director. El propio Buñuel creía que cada una de ellas podría ser la última lo que las confiere una dimensión autobiográfica que no se encuentra en otras obras.

También se evidencia en sus páginas la dependencia entre la creación y las formas de producción, y la libertad creativa que encontró en Francia respecto de su obra mexicana, tanto por la política de los autores como por los festivales. Estas nuevas circunstancias le permitieron tocar algunos temas que tuvieron mejor acomodo en Europa, lo que se traduce en una escritura fílmica que determina todo el periodo de los sesenta y setenta. En un sentido contrario Duprat establece cómo en México Buñuel tuvo numerosos condicionantes económicos, culturales y de producción.

Estas últimas películas constituyen también en palabras del autor una forma de volver a ciertos estilemas de la juventud, como si ciertos modos surrealistas fueran una forma de cerrar su obra tal y como la empezó. En estas películas España no está ausente. Lejos de eso se plantea que el universo cultural francés y español se superponen, algo así como un director español afrancesado. Sade, el Teatro de Bulevar, el surrealismo, la picaresca, el esperpento y el género Chico, son convocados como fuentes de inspiración, pero al mismo tiempo poseen una serie de giros narrativos y lecturas transversales, que son las que hacen que esas últimas obras tengan una coherencia como corpus a investigar. A 
esto podríamos añadir el tratamiento de los sueños, la comicidad absurda y el sentimiento de angustia existencialista. La conclusión no podría ser más clara. La influencia hispano-francés se mantiene en todas ellas, tanto en las referencias diegética, como en el estilo, la mirada sobre los personajes y las situaciones representadas. Las dos influencias se mezclan para formar un único universo, que puede quedar representado de forma metafórica a través de los personajes de Conchita en Ese oscuro objeto del deseo y el de Séverine de Belle de jour.

Agustín Gómez 